\title{
IO
}

\section{From one world to another}

Changing class is like emigrating from one side of the world to the other, where you have to rescind your passport, learn a new language and make gargantuan efforts if you are not to lose touch completely with the people and habits of your old life.

- Lynsey Hanley ${ }^{1}$

It is time to write again about my own experience. The book began with an essay written in response to a request from Naeem Inayatullah at a dinner after his talk in Aberystwyth in March 2007, and it was first published in 20I I. Recently, my PhD student Amal Abu-Bakare surprised me. She'd read the essay and wanted to tell me how much she'd liked it. She compared my writing to that of Ta-Nehisi Coates, in his Between the World and $\mathrm{Me}$, a book I had yet to read. ${ }^{2}$ Amal identifies herself as a black Muslim feminist; she is working to unravel the complexities of racialisation, in particular the racialisation of religion, implicated in counter-terrorism in Canada, where she's from, and the UK.

Her comments prompted me to go back and reread my own essay. I'm no longer the same person who wrote that essay, ten years ago, and many of its concerns seem very remote now. However, some remain, and some are sharpened. The writing of that essay - and what has happened since - has changed me, changed my teaching and writing, and changed my sense of what motivates me.

The original essay was hard to write. At first it was difficult impossible - to begin. It was only when my mother showed me the letter my father wrote to her after my brother's birth - described in the final paragraph of that essay - that I could start. And it was only 
Naeem's gentle but quietly persistent prompting that enabled me to continue, that opened out the writing, and that turned it into the essay that was published. The beginnings can be traced back further, to an International Studies Association (ISA) conference in San Diego, California in March 2006. I attended the session where Himadeep Muppidi read his essay 'Shame and rage' ${ }^{3}$ I did not know him then, and I've no idea what I expected, but his reading so moved me that I had to leave the session. I walked from the conference room through car parks and away towards the concrete shopping malls behind the hotel. Eventually I turned around, retraced my steps and went back into the session. I did not belong there, in that room - and yet I did. I was interpellated at one and the same time as white coloniser, responsible for the wretchedness of the earth, and as exploited outsider to my place in the world in my own right. When, much later, I told Naeem I didn't have a story to tell, he quietly insisted we all do. He is right, of course. Our stories are not our own, in any case.

In November 2008, I read my essay to an assembled audience of my colleagues and students in Aberystwyth. It was my inaugural lecture, and as tradition dictates - and as I wanted - I had invited family and friends. My mother Joan was there, and my godmother: my mother's cousin, Marjorie - daughter of the Annie who married a Catholic mentioned in my essay. In deference to my mother, I left out much of the description of my father's death. Both she and my godmother had travelled from Lytham St Annes to be in the audience. My other godmother, my mother's best friend from school, Joyce Garner, declined the invitation. Joyce had married my mother's cousin, Edwin, and they began married life in a caravan, I think, though she, unlike my mother, had been to secondary school. She now lived in a large detached house with indoor swimming pool, conservatory and carefully tended front garden overlooking the Royal Lytham golf course. She was not well enough to come - and also, always witty and down-to-earth, couldn't see the point.

When I was told I had to do an inaugural lecture, I had chosen to read the essay, first, because it was something I had written already, and second, because of my colleague Len Scott, whose inaugural was held the year before mine. He had commented, when I was given my Chair, that it had only taken eighty-five years for the department 
to appoint a female professor. He had given an amazing inaugural lecture interweaving family, academic thinking, anecdotes and wit in a way that only he can pull off. Maybe that was what made it possible for me to do something entirely auto-ethnographic: there was no way I could attempt what he had done, and yet he had opened the door for something other than the expected academic setting-out of a new professor's research agenda. I had no idea what to expect in response to my essay - but then, tradition dictates that inaugurals are not followed by questions anyway, so I would be safe.

What happened afterwards surprised me. In the reception following the lecture, a group of women PhDs surrounded me, saying how pleased they were that I'd done what I'd just done: they felt emboldened to do something similar. An old friend summarised the argument I'd made in a couple of sentences - although to others it was just a story. And in the days afterwards a colleague sent me a thank-you note and small gift, telling me that my talk had resonated deeply with her, and her relation to her own father. Others responded with their stories. After a while I forgot that I'd written this personal account, and that it was published - I was surprised when, if I said something about my background, people would say, 'Oh yes, I know.' Now that no longer happens: no one reads the story any more. That's one reason why I was surprised when Amal gave me her comments.

My godmother Marjorie responded differently. Although she never said anything to my face, my mother told me that she was angry: she thought I shouldn't have done what I did. These things were private, and shouldn't be revealed in public. Respectability was all. My mother was more forgiving: 'It's your story, and that's fine.' Much later, she pointed out inaccuracies: she was the one who'd chosen the presents my father gave to his staff every Christmas; the shortage of housekeeping money was not because of payments to my father's ex-wife but because my mother had said she could manage on less so that they could afford to move me from the local primary to a direct-grant school, where, at the age of eleven, I won a governor's scholarship. In fact she denied there had ever been any maintenance payments, although I have the evidence myself in official documents. I had seen the contents of my father's black box with my own eyes too, though I was never able to bring myself to admit this to her. 
I had not thought of my earlier essay as anything to do with class. But as Lynsey Hanley puts it, changing class can be compared with emigrating: it is disorientating and isolating. Migrants are left cut off from those they were close to in their previous life, and there is no going back. A new language has to be assimilated, new habits learned. I've only just come to realise the impact of crossing class: on relationships put at risk, on security lost, and on writing and research choices. My secret as an academic is not just that I was originally a physicist not a sociologist, but rather that I carry within me a still raw sense of injustice from the traces of another life - and not just my own. I travelled from a suburban council-house upbringing in Bristol to sherry parties hosted by Oxford dons. ${ }^{4}$ But my father was already middle class, I suppose. He wasn't a graduate - a lack that held him back throughout his career - but he took the opportunity that was offered to train as a teacher when he was demobbed after the Second World War. He was a head teacher by the time I started school. I still recognise much in Séan Richardson's blog about being a working-class $\mathrm{PhD}$, from the 'imposter syndrome' and 'anxiety about not knowing the right cues or having the correct etiquette', to 'not being able to articulate exactly what you do' to your family. ${ }^{5}$ What Hanley doesn't mention is that crossing class boundaries distances a person from their children, too: the second generation inhabits the new class with no difficulty.

My mother is the one who really made that journey - and managed to keep her feet in both camps. ${ }^{6}$ She was born in Diggle in Saddleworth on Christmas Eve I922. Her father's family lived close to the docks in Salford where he worked as a cotton packer before the war. After he was gassed in the trenches, the family moved out of Salford to the clearer air of the surrounding hills, where he could breathe better. But he died when Joan, his only child, was just two and a half. He is buried in an unmarked plot in Weaste Cemetery, a stone's throw from the Manchester Ship Canal and Old Trafford football ground. His widow and her infant moved back to St Annes to be with the extended family, including Joan's cousins Marjorie, Peter, Bob and Pauline. To Joan they were like brothers and sisters. As a child, Joan was taken back to Salford to visit her father's mother - a formidable woman by all accounts - and her cousin Edwin. When I was young we would 
still visit her aunt and uncle in Salford and go for a walk in Buile Hill Park. I can remember vividly having tea in their narrow house, with its staircase leading up from a cupboard in the front room, and the drive from there to the park on the hill. My great uncle used to press a coin into my palm as we left. Those houses are all gone now, demolished to make way for the motorway, but the cemetery is still there.

My mother's first job after leaving school at I4 was as an apprentice carpet layer, but illness forced her to give that up. At I 6 she went to work at the Meter Record Office - where she met my father, a meter reader - and from there to the railway station booking office and then the tax office. When she was first married and expecting me, the couple lived in her mother's small terraced house in Holmfield Road, St Annes. In 1950 my father took a job as a teacher in Bristol and they moved down south. A few years later they moved again, this time to Darlington, where their second child, a son, was born. But they were soon back in Bristol. My father was now a head teacher, and they settled in a council house in Westbury-on-Trym.

My mother was a traditional housewife: bringing us up and looking after her husband, her mother-in-law and her own mother. In those days women whose husbands needed to demonstrate their middle class-ness weren't allowed to work. But as soon as we were grown, she trained as a lecturer and taught in a technical college. She took early retirement shortly after my father retired. Five years later, he died suddenly: a story I told in the first chapter. My mother stayed in Bristol, busy in various ways: studying fine-art embroidery, training advanced driving assessors, baking and serving on committees for the Women's Institute. Then, in the early 2000s, as her Bristol friends began dying out, she moved back to Lytham St Annes. She immediately became, once again, part of two vastly different circles. Her cousin Marjorie's ex-council house was a regular calling point for a chat, with Pauline a few steps round the corner and Bob not far away. And she was taken out to lunch and on day trips with her old school friend Joyce and her daughter. The two circles overlapped rather uncomfortably: Marjorie was Joyce's cleaning lady.

The first essay in this book is 'about' my father. This story is about my mother. Or rather, it is about the distance between me and my mother: a metaphorical rather than a literal distance. It is the 
distance between a mother who left school at fourteen and from then on had no belief in her own considerable abilities and a daughter who has always been told she was able. It is the distance between a mother whose own mother was one of the housekeeping staff in a hotel and a daughter who stays in hideous conference hotels at international studies conventions in the USA every year, without a second thought. It is the distance between a mother who has pride in her daughter's achievements and a daughter who sees how little she has achieved in the face of the injustices of the world and is impatient with that praise: a mother who expresses her pride and a daughter who cannot bear to be singled out for attention or praise. And it is the distance between a daughter who steers clear of a mother who cannot understand what she works on and a daughter who cannot suppress the impatience she feels with a mother who will not even read a newspaper or a novel or use her considerable intellectual abilities at all.

Almost exactly a year before she died, I wrote, 'I cannot tell my mother's story - and I cannot talk to her about it.' I understood something of why when Lauren Berlant, during a conversation on the train after a conference in Salford, recommended I read Carolyn Steedman's Landscape for a Good Woman, a meditation on questions of class and belonging, materiality and loss. I first heard Berlant speak when I was two years out of my $\mathrm{PhD}$ and only just beginning to work on trauma. I went to a conference on Testimonial Cultures organised by Sara Ahmed and Jackie Stacey in May I 999 in Lancaster. ${ }^{7}$ I was keen to hear one of the speakers in particular: Cathy Caruth. She gave the paper that I quote in Chapter $7 .{ }^{8}$ Berlant spoke in Lancaster too, presenting work from Cruel Optimism, the book I draw on in Chapter 9. I next met her at a Trauma Workshop held at the University of Salford four years later.

After the workshop, we both took the train north. Berlant was on her way back to Lancaster and I was on my way to Lytham St Annes to call on my mother, who was in the process of moving back to Lancashire from Bristol. We must have fallen to talking about the often fraught relationship between mothers and daughters. Berlant must have sensed more about me than I said; she asked whether I'd read Landscape for a Good Woman. ${ }^{9}$ I hadn't, but I did immediately 
afterwards. The conversation made connections for me that I hadn't made before at all, about the personal promptings for the work on trauma I had been doing. Steedman's book relates to my background in many ways: Berlant put her finger on something very precisely with that suggestion. I wrote to her, 'I think I keep trying to repress the insights from what you said ... and at the same time looking for a way to bring such concerns more into my work.' Maybe, in this book, I am finally attempting something like this.

Steedman talks about 'lives for which the central interpretative devices of the culture don't quite work'. ${ }^{10}$ For all lives to some extent, but for these lives particularly, 'specificity of place and politics has to be reckoned with'. Her mother was very much like mine: 'From a Lancashire mill town and a working-class twenties childhood she came away wanting: fine clothes, glamour, money; to be what she wasn't.' ${ }^{11}$ Though my grandmother was the one who worked in the Lancashire mills as a girl, this account helped me grasp some of the contradictions I felt in my mother.

She read my books - or rather, started to read some of them. After her death these books came back to me. The three of them died together: Marjorie, Joan and Joyce. In the space of one year I lost my mother and my two godmothers. My two other role models and confidantes, my mother-in-law and my stepmother-in-law, had both died many years before, in the early I990s.

I have always found in Frantz Fanon's writing, and particularly Black Skin, White Masks, something that spoke to me at a profound level. ${ }^{12}$ His work provided the epigraph and inspiration for Chapter I, 'Objects among objects', and the book, and Isaac Julien's film, have always been the first texts in my postcolonial politics syllabus. Fanon was from a middle-class family that could afford to send him to a good school. And he was black. I am neither.

Class is a form of racialisation. Not in any sense as brutal as other forms, for sure, but, like race and gender, class defines, separates and excludes. It draws lines. It cannot be likened to the racism Coates recounts. ${ }^{13}$ Nor can moving from one class to another be compared with other, more dislocating and dangerous journeys. But it does give some sense of what those other, greater dislocations and vulnerabilities might feel like. Class origin can be, and often is, hidden. 
On the surface it is perfectly possible to pass as from another class background. Expressions, ways of dressing, manners and mannerisms can all be acquired, often unconsciously, such that one can only be 'outed' by someone else from the same roots. But discomfort and dislocation persist. Perhaps, even, as Naeem Inayatullah has suggested to me, because class is less visible, it is less accessible than other forms of difference, and hence - and this is my interpretation - more difficult to acknowledge and contest. ${ }^{14}$ Maybe they work together; maybe, as Gurminda Bhambra and John Holdwood put it, 'class is race, and addressing their mutual formation will be central to any future organisation for social justice'. ${ }^{15}$

For Robbie Shilliam 'race' is 'the hierarchical adjudication of human competencies through the categorizing of group attributes, wherein groups are identified by some kind of shared heritage that is deemed visually identifiable'. ${ }^{16}$ For me, this does make class more or less a racial category. Richard Dyer says in White: Essays on Race and Culture that 'the myriad minute decisions that constitute the practice of the world are at every point informed by judgments about people's capacity and worth, judgments based on what they look like, where they come from, how they speak, even what they eat, that is, racial judgments'. ${ }^{17}$

People's class is judged in precisely this way: by their appearance, what neighborhood they're from, their accent, and what they call their meals. Lynsey Hanley writes:

I can't remember the day I started calling dinner 'lunch' and tea 'dinner', but I know that it happened, because that's what I call them now. That must mean I'm middle class, where once I was working class. ${ }^{18}$

Most people I meet these days have no idea what sort of meal tea was when I was a child: bread and butter always, a pot of tea of course, and something hot like scrambled eggs or baked beans or cheese on toast, and maybe a sweet, too (we didn't call it 'a pudding' or 'a dessert'): tinned peaches, perhaps, or a home-made sponge cake. I find I cannot remember the details, and I'm not sure I could still set the table for it, though that used to be my job - alongside carefully buttering the bread, cutting it into triangles and setting it out in neatly 
overlapping rows on a large plate. I am almost ashamed to admit to this knowledge, in print.

Kenan Malik argues that 'race developed initially as a response to class differences within European society'. ${ }^{19}$ He writes:

Today, the concept of race is so intertwined with the idea of 'colour' that it is often difficult to comprehend the Victorian notion of race. For the Victorians, race was a description of social distinction, not of colour differences. Indeed, the view of non-Europeans as an inferior race was but an extension of the already existing view of the working class at home and took a considerable time to be established as the normative view. ${ }^{20}$

The working class was not only socially, economically and culturally distinct; to the Victorians, those distinctions were biological and inherited, passed from generation to generation. Whereas in the I960s, social policy was aimed at overcoming those differences, by the I990s both New Labour and the conservatives in the UK built policies around the notion, Malik argues, that these differences (and the resulting inequality) were natural and could not be overcome. Although Malik claims that 'today, elite views of the working class are rarely racialized, at least in an overt fashion', covert discrimination remains. ${ }^{21}$

One of the outcomes of a social or political order based on such divisions (and gender must be included here) is that people are objectified: they become 'an object in the midst of other objects' ${ }^{22}$ It is no longer the unique and irreplaceable being - the 'qui' - that is seen, but only the 'quoi'. ${ }^{23}$ We no longer see $w$ ho people are, but only what they are. Lines are drawn and a particular form of power, authority and control is established. People are interpellated into subjects, that is, objects.

Coates's book begins with searing accounts of his childhood and youth. Though vulnerable, as any young girl was, to sexual abuse, I have never experienced anything remotely comparable to the fear and violence he describes. The council house I was brought up in was not on an estate, but in a I930s suburb, surrounded by middle-class, owner-occupied, semi-detached houses. I was moved away from the boys' taunting at the local primary when I was seven. I attended 
an all-girls school and then an Oxford women's college. About to graduate, and be thrown back out into the world, I went to the university's careers office. The cyclostyled sheets I was handed describing the various openings available would often state, baldly, at the top: 'Women need not apply'. This was I970, before the UK's Sex Discrimination Act came into force, outlawing such practices. Suddenly, at a stroke, unexpectedly, my privilege was withdrawn. I had seen myself as 'a universal subject' but I discovered I was 'one upon whom the universe had closed its doors' ${ }^{24}$ The body I inhabited was not good enough, though middle class by then it surely was. It still isn't, of course: less than twenty-five per cent of professors are women, and there is a significant pay gap.

Coates describes how he came to think of being black as not to do particularly with skin colour:

Perhaps there had been other bodies, mocked, terrorized, and insecure. Perhaps the Irish too had once lost their bodies. Perhaps being named 'black' had nothing to do with any of this; perhaps being named 'black' was just someone's name for being at the bottom, a human turned to object, object turned to pariah. ${ }^{25}$

Closer to home for me, Carolyn Steedman reflects on her enduring consciousness of class difference:

I read a woman's book, meet such a woman at a party (a woman now, like me) and think quite deliberately as we talk: we are divided: a hundred years ago I'd have been cleaning your shoes. I know this and you don't. ${ }^{26}$

As Lynsey Hanley puts it, moving from one class to another is a journey from one world to another. It entails loss as well as anything positive, and it leaves one's inevitable incoherence and incompleteness palpable. In a way, then, so-called social mobility is similar to being 'almost the same, but not white'. ${ }^{27}$ One dons a mask and builds a self, but one that remains always fragile and vulnerable, subject to unmasking at any moment. The new self is often unaware of its fragility, until interpellated otherwise: 'Look, a Negro'. ${ }^{28}$

An awareness of the vulnerability and multiplicity of the self is not necessarily a bad thing. All 'selves' are vulnerable - or, as I've put 
it elsewhere, 'missing'. ${ }^{29}$ The self - the 'individual' of contemporary politics - is a comforting fantasy, nothing more. Some people are blissfully oblivious of this fact, as Steedman points out: an ignorance that goes along with privilege. Although invited to the party - interpellated as a middle-class liberal subject - she is aware that this is not all she is, or maybe even not who she is. We can assume that she goes along with it all, chatting to the woman she meets. But all the while she 'quite deliberately' maintains a distance, one visible only to herself, but one that enables her to preserve the complicated, incoherent person she recognises herself to be, in the face of attempts to interpellate her as a coherent 'subject'. She refuses to misrecognise herself as 'like' the other woman, but she shows up at the party anyway.

Interpellation is the process of 'hailing' whereby 'concrete individuals' are transformed into subjects. Louis Althusser's famous example is the 'Hey, you there!' uttered by a policeman. ${ }^{30}$ When we recognise ourselves in the officer's call and turn round, we are interpellated into a particular subject position: we become subjects of the police order, in Jacques Rancière's terms. ${ }^{31}$ Interpellation 'establishes and cements authority and social norms', but according to James Martel it does more, 'establishing even the sense of individual identity'. ${ }^{32}$ A person becomes a subject - and an individual - 'by this mere one-hundred-and eighty-degree physical conversion'. ${ }^{33}$ And yet, interpellation doesn't quite work: there is always a leftover: we are always both more that the subject we are hailed to be, and less. We never quite fit. In the Lacanian thinking that Althusser draws on, interpellation positions us in the social or symbolic order, but that order is always incomplete. There is always a lack - a surplus or an excess - that the symbolic cannot capture.

Not only is the person who turns around sometimes not the intended subject of the call, as Althusser admits, but interpellation always fails: we are all misinterpellated subjects, as Martel puts it. His book makes what for me are two crucial arguments. First, he points out that if the person who turns up - or turns around - is not the one to whom the call was addressed, it can be world-shattering. For example, he sees the Haitian revolution as a response to the French Declaration of the Rights of Man and Citizen - a call taken up by Haitian slaves, though it was never addressed to them - which then fed back into France, 
radicalising what happened there. Misinterpellation, in other words, 'works as a specifically and dangerously political force'. ${ }^{34}$ It holds a radical potential that can help 'rethink or enhance our approach to politics, to authority, and even to revolution'. 35

Second, he links interpellation with colonisation. It means imposing an identity on persons, overwriting their multiplicity and violently incorporating them into an alien way of being. We are all interpellated, and answering to that interpellation - accepting the identity to which we are called - is accepting a colonising move. Decolonisation 'is waged against interpellation itself'. Martel sees Fanon as 'the misinterpellated subject par excellence', in that he 'takes on the responsibility of deciding for himself what his blackness is and means, and in that way he both refuses and stands in his given subject position'. Decolonisation involves accepting 'the subordinate subject position [we are] forced into and [turning] it against the very submission it is meant to instill'. ${ }^{36}$ The North Kensington community could be seen as doing precisely this in the aftermath of Grenfell. Misinterpellation calls into question the whole process of subject formation and is ultimately a challenge above all to capitalism itself, as well as the ideology of individualism that sustains it'. ${ }^{37}$ The task, as Martel sees it, is to figure out how to amplify the damage - to refuse and resist interpellation and the colonised subject it produces - and how to build other ways of calling each other and a community into being. Accepting interpellation is of course easier and more comforting since it gives us the fantasy of belonging, but that fantasy is fragile.

Those who cross the class divide are misinterpellated subjects: we respond to the call to be intellectuals, leaders, theorists, despite the fact that we recognise all too clearly that the call is not addressed to us but to the middle or upper classes. But if, when we become middle class, we take on middle-class ways of thinking and acting and espouse middle-class values, the misinterpellation is no longer resistance in Martel's sense. We have merely swelled the ranks of the oppressors and buttressed the barrier we so recently crossed. If, as academics, we conceal our origins, adopt established pedagogical and writing styles, and focus on our careers, we might be able to conceal our anxiety, overcome our impostor syndrome, and blend in. But any critical advantage that our complex background and 
our dislocation might afford us will have been lost. We will be no better placed than the next person to decipher the contradictions of authority or resist the decimation of education. We will repeat the acts of the colonisers.

The alternative, following Martel's discussion of Fanon, is decolonisation: refusing the framework of interpellation and the production of subjectivity, and working to reveal alternative forms of personhood. It involves becoming someone who quite deliberately remembers where she came from and what this means for her encounters now. In a sense the misinterpellated subject is one who has traversed the fantasy in the Lacanian sense, one who no longer accepts the comfort of a knowable and securable world but recognises the impossibility of completeness or closure. ${ }^{38}$ The misinterpellated subject is not a 'subject' at all but a person, or what I have called a person-as-such, and a person resists objectification and instrumentalisation. A person is the qui not the quoi, the neighbour not the biopolitical subject. ${ }^{39} \mathrm{In}$ pedagogical terms, the alternative is difficult and yet vital: education is at the heart of the project of interpellation that produces future docile citizen-subjects. Nevertheless, we can begin from the assumption, following Martel's assertion that we are all misinterpellated, that our students already know what is going on.

My mother's death, and her way of dying, showed me many things. Her wisdom, first and foremost. I found that although I had continually been trying to convince her that her intelligence was equal to that of any academic, in my thinking she was still lacking - in education, in reading, and so on. I had always known she was an agile thinker - seeking advice but not taking it, working in sometimes oblique or even underhand ways to get the outcome she wanted. But I had not realised the extent of her fundamental wisdom. How I wish I had grasped this before, when she was still in this world. She embraced forms of knowing that do not come from books. Hers was an embodied, situated knowledge. She was perceptive, knew how to control from beneath, and how to support with understanding and insight. She had a strong sense of rightness, and was willing to stand up to authority. Working in the ticket office in St Annes Station, she was approached one day by the man who owned the railway, who demanded to travel without buying a ticket. She demurred. 'You 
know who I am', he insisted. She stood firm, and he paid his fare like everyone else.

It also showed me something else. Towards the end of my earlier essay, I wrote: 'I am my father's daughter, nothing more, despite any feeling of having made my own route in the world.' I now think that I am also, in a perhaps more profound or at least more embodied sense, nothing more than another incarnation of my mother, though without her wisdom. I don't know why I should be surprised by this, although it is obvious from the story so far.

In the course of less than six months, through a sorry saga of hospitalisation, poor treatment and missed chances, my mother went from an active, busy, independent woman to a mere shadow of herself physically. She must have had some intimation of this, though. Over the summer we'd had a conversation about wills and funeral arrangements, even down to the hymns she would like: 'God be in my heart' and 'Morning has broken'.

Summoned to the hospital one bleak day in March, we watched at her bedside. We were told she wouldn't last through the night, but she did. At around I a.m. my brother and his partner left. I promised to contact them if there was any change. I focused all through the night on her face and her breathing. Steady, regular, uninterrupted. Then, at 8.30 in the morning, as the nurses arrived to turn her, the breathing stopped. There was a long pause. Then she took a breath: smooth, unforced. Then another long pause. Then another breath, again, not laboured or difficult. Then nothing. Her heartbeat continued for some moments. And then it too stopped. After a while the young nurse who had stayed at my request left, and I went back to the chair I had been sitting in. At that point, the grey March dawn outside the window opened into rays of sunshine that entered the room. Morning had truly broken.

The following day, I woke and looked in the mirror. She looked back at me. My face was her face. She was there still in me. I carry her with me always. One person inside another, or one world still alive in another one.

Politics - and international politics especially - makes us who we are, and regulates the ways we inhabit the world, and our journeys through it: across class boundaries, across continents, from life to 
death. The distinctions, inequalities and hierarchies that are imposed by and on us determine the ease or otherwise of that habitation and those journeys.

During an interlude in her hospitalisation, my mother was moved to what was described on its website as 'a community unit that provides sub-acute and fast-stream inpatient and day hospital care for older people', whatever that means. Things promised on that same website were not available in reality. When I visited, I would travel by train, talking the bus from St Annes train station and then returning by walking on to the station one stop further down the line at Ansdell. Conditions in the 'unit' were appalling: food she couldn't eat, a tiny television she couldn't see, a 'day room' with patients parked unattended for hours on end, and a constant wailing from the ward's dementia patients. After my visits, I would escape to the world outside, and walk to the station. The short distance took me past large detached mock-Tudor houses, set well back from the road, with closely manicured gardens and spacious drives. I wept at the transition from public squalor to private excess.

In the end my mother could no longer put up with it. Her one aim was to get out of hospital, and she found the only way to do that. Four days before she died she had me write in a thank-you card to some friends: 'I hope to be out of hospital very soon.' She couldn't make her fingers sign her name.

While Stuart Hall's classes in sociology and social theory enabled me to see much that I had been blind to before - it was a revelation, as I wrote in Chapter I - entering the discipline of international relations in 1993 required me to forget most of what I had learned. I was expected to enter a world where 'nations' or 'states' spoke with one voice and no history, where there were 'agents' and 'structures', and where identities might be 'multiple' but were still 'constructed' - a self-referential world, circulating around itself, defined by the concept of 'the international'. As Marysia Zalewski put it, there were 'all these theories and yet the bodies keep piling up'. ${ }^{40}$ It was only much later that dissenting voices from the margins became truly audible, and the discipline was outed as a veritable 'world school of colonialism'. ${ }^{41}$

The idea of decolonising the discipline has now become the latest of a series of 'turns', alongside, among so many others, the 'narrative 
turn' and the 'aesthetic turn'. While these 'turns' have opened thinking space, in my view as long as there remains the idea that a discipline of international relations is possible, thought will remain confined within the boundaries of the world as we think we know it. Or rather trapped within the borders of a particular, racist, classist and gendered world sustained by the concepts and theories destined - and designed - to reproduce it.

There is no place in that world for the people we encounter every day: irreplaceable, contradictory, unfathomable beings, whose stories testify to another world and another way of being. These people exist: they are not part of some future utopia. It's just that we are blind to them: we cannot see them; they do not fit our theories. Indeed, 'theory' itself cannot grasp them. Their complexity eludes the reach of abstract conceptual thought. They cannot be generalised.

I should reach for citations and argument to substantiate these claims, or so I am told. I should reference Jacques Derrida's work on the phallogocentrism of Western metaphysics; I should cite Michel Foucault's Order of Things to show how disciplines make the worlds they purport to explain; I should not just assert what I have come to know. Or, at the very least, I should not claim that what I say is worthy of being called 'knowledge'.

Should I cite the hospital records to corroborate my account of my mother's death? What should I cite to prove that she looked back at me from the mirror that day after? Should I have taken a selfie to document the plausibility of my story, or, maybe, just maybe, could I leave it to my readers to judge?

In studying global politics, should we not, rather, especially given the violence of our subject matter, purge our tongues, and 'set aside' all we 'know or believe about nations, wars, leaders, the governed and ungovernable', as Toni Morrison does when she addresses the dead of September I I: 'those children of ancestors born in every continent on the planet: Asia, Europe, Africa, the Americas ...; born of ancestors who wore kilts, obis, saris, geles, wide straw hats, yarmulkes, goatskin, wooden shoes, feathers and cloths to cover their hair'. ${ }^{42}$ The discipline of international relations brings to life only those it can stomach. I'm sure I'm not the only one to be troubled by this, but this is what many who work in the discipline have to buy into, and we are 
asked to teach our students to forget all they know, before they reach us, of their formation by race, class and gender and buy into it too.

Coates writes: 'My great error was not that I had accepted someone else's dream but that I had accepted the fact of dreams, the need for escape, and the invention of racecraft. ${ }^{43}$ We teach students that they are separate from the world and can change it. We do not teach them that this notion might be what produces that world and its manifold injustices in the first place.

Steedman's mother wanted 'fine clothes, glamour, money'. In the early I970s, at the time when Derrida and Foucault were writing, and not long after Fanon's Black Skin, White Masks had appeared in English, John Berger made a documentary series for the BBC called Ways of Seeing. 4 'Glamour', he wrote in the accompanying book, 'cannot exist without personal social envy being a common and widespread emotion.' Our contemporary world provides the ground for such an emotion: as Berger says, people 'live in the contradiction between what [they are] and what [they] would like to be'. Compounded with a sense of powerlessness, envy 'dissolves into recurrent day-dreams' ${ }^{45}$ We are 'situated in a future continually deferred [that] excludes the present and so eliminates all becoming, all development. Experience is impossible within it. All that happens, happens outside it.' ${ }^{46}$

Or, as Oskar Negt and Alexander Kluge put it, slightly differently:

The proletariat makes experiences on its own; their evaluation is carried out by leaders, theoreticians, writers, who in their mode of production are located in a substantive and, by intent, emancipatory context but who, in formal terms, constitute a bourgeois public sphere. ${ }^{47}$

Is what we sell the glamour of a university degree? The promise that once acquired, it will make life better, more enviable? Is what we write, and what we teach our students to write, the evaluation of others' experiences in our own terms? The imposition of order upon difference, the conceptual upon the inexpressible, in the name of emancipating those others? What if we wrote our contradictory, complicated selves into the teaching and the writing, and allowed our students to do the same? Or is that just another fantasy? Can we academics, whatever our origins, our histories, learn to give 
up on the fantasy, to live in, not apart from, the world, and to acknowledge and accept the vulnerable, mortal, irreplaceable beings intimately conjoined with each other and the universe that we are?

To use Martel's terms, we are all interpellated - colonised - but that interpellation is always a misinterpellation, whatever our class position. We need to find ways of amplifying that, and drawing out its subversive power. This essay, and this book, have tried to bring back, not the political as in the subtitle of my first book, which of course is always there, but the person. The acknowledgement and acceptance of ourselves as the incoherent, chaotic and untameable mortals that we are, the subject of no lack other than that which is apparently imposed on us, and which we seem to accede to ourselves, is key. Only then - decolonised - can we see the questions of international politics otherwise, and begin to enhance and make visible - or rather stop hiding - the already existing alternatives to contemporary forms of power. Or is this a fantasy too?

I underestimated my mother. Perhaps because I had learned to see myself as male, middle class, privileged. For me she seemed to be all that I was not: female, subservient, working class - wanting glamour, fine clothes and a detached house. I was always pushing her away, closing myself off from her. Racialising her, even. I think she knew this and accepted it. Having arrived in my new location, my insecurity, my shame, perhaps, made me resist anything that could endanger that position. I wanted glamour of another sort.

\section{Notes}

I Lynsey Hanley, Respectable: Crossing the Class Divide. London: Penguin, 20I7: $\mathrm{x}$.

2 Ta-Nehisi Coates, Between the World and Me. Melbourne: Text Publishing, 20I 5 .

3 Himadeep Muppidi, 'Shame and Rage: International Relations and the World School of Colonialism.' In Interrogating Imperialism: Conversations on Gender, Race and War, edited by Robin L. Riley and Naeem Inayatullah, 5I-62. Basingstoke: Palgrave Macmillan, 2006.

4 Public housing, owned by the local authority and rented out, often, after the war when housing was short, to those like my father who were regarded as vital workers. Now called 'social housing', it is, as we saw in 
the case of Grenfell, much reduced in availability and even more looked down on than it was at the time I am talking about here.

5 Séan Richardson, The trials of being a \#workingclassphd. 27 July 2017. https://richardsonphd.wordpress.com/2017/07/26/workingclassphds/.

6 Paul Gilroy's discussion of camps and the 'between camps' mentality is relevant here. While he discusses the diaspora as between camps in the case of racially defined camps, the class diaspora - those who have crossed the class divide - could constitute such a position in the case of class-based 'camps' (Paul Gilroy, Between Camps: Nations, Cultures and the Allure of Race. London: Penguin, 2000: 82-5).

7 Sara Ahmed and Jackie Stacey, eds, 'Testimonial Cultures.' Cultural Values 5, no. I (200I): I-I30.

8 Cathy Caruth, Literature in the Ashes of History. Baltimore, MD: Johns Hopkins University Press, 20I3.

9 Carolyn Steedman, Landscape for a Good Woman. London: Virago, I986.

Io Steedman, Landscape for a Good Woman, 5 .

I I Steedman, Landscape for a Good Woman, 6.

I2 Frantz Fanon, Black Skin, White Masks. Translated by Charles Lam Markmann. London: Pluto, I986.

I3 Coates, Between the World and Me.

I4 Naeem Inayatullah, personal communication, August 2017.

I5 Gurminder K. Bhambra and John Holmwood. 'Colonialism, Postcolonialism and the Liberal Welfare State.' New Political Economy (2018). http://dx.doi.org/I0.1080/I3563467.20I7.I4I7369, I I.

I6 Robbie Shilliam, 'Race in World Politics.' In The Globalisation of World Politics, edited by John Baylis, Steve Smith and Patricia Owens, 28 5-300. Oxford: Oxford University Press, 2017: 286.

I7 Richard Dyer, White. London: Routledge, I997: I.

I8 Hanley, Respectable.

I9 Kenan Malik, The Meaning of Race: Race, History and Culture in Western Society. Basingstoke: Palgrave Macmillan, 1996: 7-8.

20 Malik, The Meaning of Race, 9I.

2I Kenan Malik, 'Echoes from the Past: The Racial view of Class.' Pandaemonium, I8 August 20I6. https://kenanmalik.wordpress.com/ 20I6/08/1 8/echoes-from-the-past-the-racial-view-of-class.

22 Fanon, Black Skin, White Masks, I09.

23 Derrida. Directed by Kirby Dick and Amy Ziering Kofman. Jane Doe Films, Inc., 2002.

24 James R. Martel, The Misinterpellated Subject. Durham, NC: Duke University Press, 2017, 96.

25 Coates, Between the World and Me, 55.

26 Steedman, Landscape for a Good Woman, 2.

27 Homi Bhabha, The Location of Culture. London: Routledge, 2004: I 28.

28 Fanon, Black Skin, White Masks, 82. 
29 Jenny Edkins, Missing: Persons and Politics. Ithaca, NY: Cornell University Press, 20I I.

30 Louis Althusser, 'Ideology and the State.' In Lenin and Philosophy and Other Essays. Translated by Ben Brewster. London: NLB, I971: I63.

3 I Jacques Rancière, Disagreement: Politics and Philosophy. Translated by Julie Rose. Minneapolis: University of Minnesota Press, I999.

32 Martel, The Misinterpellated Subject, 35.

33 Althusser, 'Ideology and the State', i 18.

34 Martel, The Misinterpellated Subject, 35.

35 Martel, The Misinterpellated Subject, 7.

36 Martel, The Misinterpellated Subject, 105-8.

37 Martel, The Misinterpellated Subject, 42.

38 See, for example, Slavoj Žižek, The Sublime Object of Ideology. London: Verso, I989.

39 Eric L. Santner, 'Miracles Happen: Benjamin, Rosenzweig, Freud, and the Matter of the Neighbor.' In The Neighbor: Three Enquiries in Political Theology, edited by Slavoj Žižek, Eric L. Santner and Kenneth Reinhard, 76-I33. Chicago: University of Chicago Press, 2005.

40 Marysia Zalewski, "“All These Theories and yet the Bodies Keep Piling Up": Theories, Theorists, Theorising.' In International Theory: Positivism and Beyond, edited by Steve Smith, Ken Booth and Marysia Zalewski, 340-53. Cambridge: Cambridge University Press, I996.

4I Richard K. Ashley and R.B.J. Walker. 'Speaking the Language of Exile: Dissident Thought in International Studies.' International Studies Quarterly 34, no. 3, special issue (I990); Himadeep Muppidi, The Colonial Signs of International Relations. London: Hurst \& Co., 2012.

42 Toni Morrison, 'The Dead of September i I.' Vanity Fair, November 200I, 48-9.

43 Coates, Between the World and Me, 56.

44 John Berger, Ways of Seeing. London: BBC and Penguin, I972.

45 Berger, Ways of Seeing, I 48.

46 Berger, Ways of Seeing, I 53.

47 Oskar Negt and Alexander Kluge. Public Sphere and Experience: Toward and Analysis of the Bourgeois and Proletarian Public Sphere. Translated by Peter Labanyi, Jamie Owen Daniel and Assenka Oksiloff. London: Verso, 20I6: 20I. 